\title{
Possibilities in 3D Printing by Radiosurgical Operations
}

\author{
M. Šramka1* ${ }^{*}$ E. Ružický \\ ${ }^{1}$ Department of Stereotactic Radiosurgery, OUSA and VŠZaSP St. Elizabeth, Bratislava, Slovakia \\ ${ }^{2}$ Faculty of Informatics, Pan-European University, Bratislava, Slovakia \\ Email: ^msramka@ousa.sk
}

How to cite this paper: Šramka, M. and Ružický, E. (2016) Possibilities in 3D Printing by Radiosurgical Operations. Journal of Biosciences and Medicines, 4, 18-22. http://dx.doi.org/10.4236/jbm.2016.412003

Received: September 26, 2016 Accepted: November 24, 2016 Published: December 1, 2016

\begin{abstract}
Introduction: In planning of radiosurgical therapy is crucial the precision in drawing target bearing and in demarcation to the risk structures. Shape and location of the tumor before the procedure can be previewed via $3 \mathrm{D}$ printing. $3 \mathrm{D}$ printing helps in deciding which modality of irradiation is the safest therapy for patient. It helps the surgeon to decide the way of radiotherapy (e.g. Linac treatment, Gamma knife, Cyberknife or proton beam irradiation). Material and Methods: Planning of stereotactic radiosurgery operation was performed by CT and MRI images. Files CT slices have, after the merger of CT and MRI images transferred to the virtual planning system. Subjectivity of manual plotting that makes neurosurgeon using a 3D model helps to visualize and optimize treatment. Specifically, 3D visualizations and $3 \mathrm{D}$ printing was performed by the software to segment data. We have created a $3 \mathrm{D}$ model of the tumor with visible anatomical structures of the brain. 3D printing technology we used software TomoCon from TatraMed and corresponding 3D printer. Conclusion: 3D printing increases the exactness of focusing on the planning procedure, determine the effective therapeutic dose, it affects the calculation of the lowest dose in risk structure and effectiveness of radiation treatment in order to preserve the highest quality of life after surgery.
\end{abstract}

\section{Keywords}

3D Printing, Radiosurgery, Quality of Life

\section{Introduction}

In the 80 s of last century, Charles Hull invented 3D printing also called "Stereolithography". This system uses the format ".stl to" interpret the data in CAD file (Computer Aided Design) and allows them to electronically transform to 3D printer. 
With an indication of the shape may include data on color, texture and thickness of the printed object.

Since the beginning of our millennium 3D printing is applied in medicine for creating individualized dental implants and prostheses. In recent years, 3D printing is applied in clinical practice but also in undergraduate and graduate education [1] [6] [7] [8].

In the planning radiosurgery operation, it is critical accuracy of target and limit risk bearing structures. The shape of the tumor, its borders and localization before surgery can be displayed using 3D printing to help in decision making. In this way, the irradiation modality safest for the patient, if it is radiation therapy, or a LINAC treatment gamma knife (Leksell Gamma Knife), Cyberknife or proton radiation [4] [6].

The result of 3D printing object depends from the printed material as well as from the type of printer (e.g. printer speed and resolution). Printing technologies are able to form the desired templates for virtual models of objects (modeled needed shapes and textures). The 3D printer creates the base of object, moving of printer head and loading material in the $x-y$ plane, and gradually creates layers of printed object with respect to the vertical axis $\mathrm{z}$.

$3 \mathrm{D}$ printing uses the outputs of the various layers of $2 \mathrm{D}$ imaging methods such as $\mathrm{X}$-ray, computed tomography (CT), magnetic resonance imaging (MRI). CT and MRI images of slices of the body will be transformed into 3D models with display of anatomical structures. This creates the $3 \mathrm{D}$ virtual object according to the model.

\section{Materials and Methods}

Planning of stereotactic radiosurgery operation was performed by CT and MRI sections of 2D images. These virtual combined slices from merged CT and MRI images have been transferred to the planning software system, which allowed better definition of the edges of the volume and structure of the target (the tumor) and identify necessary anatomical structures. Distinguish tumor from normal tissue, particularly of critical structures is done for reasons of protecting critical structures with the limit radiation doses.

Critical risk structures such as lenses, optic nerves, optic chiasm, brain stem, pituitary, are outlined in the planning program. Drawing of the skin is used to calculate the penetration depth of the beam. Subjectivity of manual plotting that makes neurosurgeon using a 3D model, helps to visualize and optimize treatment. Precision plotting target structure and critical structures in real space is enhanced by the planning program.

Segmentation of data we used in planning program TomoCon for better viewing of $3 \mathrm{D}$ objects and $3 \mathrm{D}$ printing. In this way we created a $3 \mathrm{D}$ virtual model of the object as well as the tumor visible anatomical structures of the brain to the press. Then we used the software TomoCon from TatraMed for 3D Printing necessary structures. This process $3 \mathrm{D}$ model structures and 3D printing we applied for one patient with a tumor of the optic nerve and the patient with two tumors, one situated near the weir and the 
other near the vessel, but at a safe distance from the ocular structures (meningioma).

Before the stereotaxic radiosurgical treatment indication we made 3D model of the patient's brain with the tumors and critical structures (see Figure 1). The tumor is located directly on the optic nerve, so we decided to fractionated radiotherapy by stereotactic gamma knife brain surgery to not damage the eye of the patient.

The second patient has two tumors, one lying near the sluice and other nearby vessels, but at a safe distance from the ocular structures, so we decided to stereotactic radiosurgery operation (see Figure 2). This patient was successfully operated in one radiosurgery session without damaging critical structures.

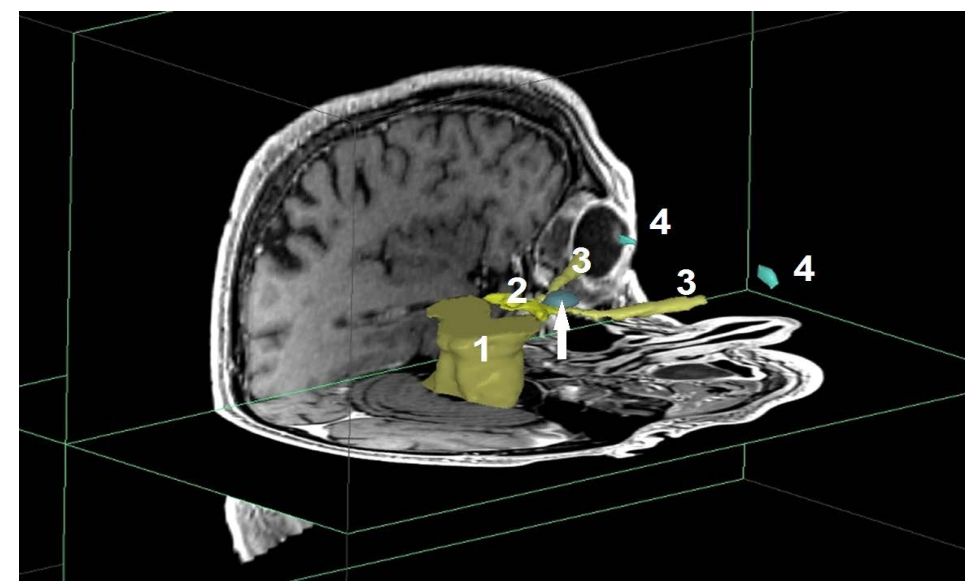

Figure 1. Sagittal section view of the brain with 3D imaging of meningioma on the optic nerve-the arrow indicates the tumor bearing, which lies directly on the optic nerve. Risk structures are numbered: 1 . brain stem, 2. optical chiazma 3. optic nerves, 4. lens.

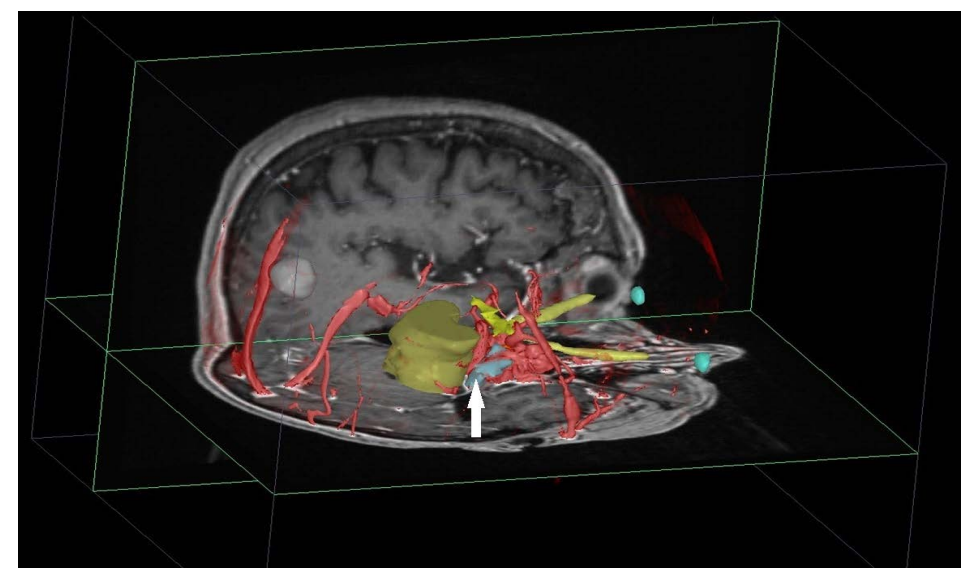

Figure 2. View sagittal section of the brain with a 3D finding meningioma near sluice and blood vessels-in this patient are two tumors, one occipital behind, touches the occipital sluice. The tumor is light blue, indicated by the arrow. A second tumor is in a tangle of blood vessels in the jugular foramen the optic nerve several millimeters below it, also the same light blue color. Radiosurgery procedure must protect at-risk structures-lenses, optical chiazma, brainstem and blood vessels in the jugular foramen. 


\section{Discussion}

In collaboration with physicians from the Ophthalmologist clinic of the Faculty of Medicine in Bratislava we planned radiosurgery operations of the brain and eye using program TomoCon. Before the operation we created 3D models of the necessary structures and printed to the 3D printer, which we use them for postgraduate teaching of physicians and medical students in stereotactic radiosurgery operation of the brain and eye tumors.

Presently 3D printing models in medicine are developed in clinical place of work such as Cardiac surgery, Dental Surgery, Ophthalmology, Orthopedics and others [1] [8].

These procedures can significantly, as diagnostic as well as therapeutic, to interfere in the management of patient treatment and student teaching.

At stereotactic radiosurgery treatment plays an important role in the formation of the layout plan, the shape of the tumor, as well as distances and bearings to critical structures. 3D tumor imaging with visible anatomical structures of the brain helps to determine the best modality of the therapy. These procedures ensure optimal treatment strategy for maintaining the highest quality of life after irradiation.

In stereotactic radiosurgery $3 \mathrm{D}$ printing helps us for deciding which modality radiation is optimal for the patient. As an example we list treatment by these devices: Linac, Gamma knife, Cyberknife or proton therapy. We decide between them in order to preserve the highest quality of life after surgery.

The model created by 3D printing helps in improving the vision of the operator of the tumor as well as in the actual planning process [3]. The ability to see the 3D structure of the head with tumor process is beneficial to the whole team that creates the radiosurgery plan (clinical physicist, stereotactic radiosurgery, radiotherapist, ophthalmology and radiology). 3D spatial perception contributes to a better understanding of the location and progression of tumors compared with the creation of perception from the series of $2 \mathrm{D}$ views only.

Objective is to optimize the health of each patient. The related decisions must be in the future is no more on the experiment, but the right decision. The new phenomenon "Big Data analytics" has to help towards this objective that active use of large amounts of data is changing the way of decision-making.

It is believed that in terms of rapid analysis of various data related to the actual processing and evaluation of $3 \mathrm{D}$ imaging, for example in the preparation of $3 \mathrm{D}$ printing, Big Data analytics plotted target bearing and limiting the risk structure to speed up decision-making process when planning of radiosurgery operation. In the near future, such systems will be transformed into a complete ecosystem health, and by implementing cost-effective measurement choice and better use of resources and measurable value in a global sense [2].

\section{Conclusions}

The possibilities of 3D printing we used in neuro-oncology in order to decide which 
modality radiation is most appropriate for the patient in order to maintain the highest quality of life after surgery.

When planning radiosurgery operation is crucial plotting precision target of bearing and limit risk structure. The above-mentioned shape and boundaries, we have succeeded to display through $3 \mathrm{D}$ printing. In this way, we have increased exactness targeting therapeutic dose during the planned intervention, and consequently affected the calculation of the lowest dose to risk structures.

3D Printing contributes to a better understanding of localization and progression of tumors with creating of imagination spatial arrangement through regular 2D slices that assist in undergraduate and postgraduate education.

\section{References}

[1] Furdová, A., Furdová, Ad., Thurzo, A., Šramka, M., Chorváth, M. and Králik, G. (2016) Možnosti 3D tlače v oftalmológii-prvé skúsenosti pri plánovaní stereotaktického rádiochirurgického zákroku u vnutroočného nádoru. Čes a slov. Oftal., 72, 80-83.

[2] Ranjan, J. (2016) Big Data Applications in Healthcare. In: Big Data: Concepts, Methodologies, Tools, and Applications. IGI Global, Chapter 56. http://dx.doi.org/10.4018/978-1-4666-9840-6.ch056

[3] Šramka, M., Ružický, E., Chorváth, M., Furdová, A., Králik, G., Kajan, J. and Mazan, P. (2016) 3D model stereotaktických radiochirurgických operácií hlavy. VIII. Sympózium neurológov a neurochirurgov na Zemplínskej Šírave, 2 a 3 júna 2016.

[4] Schubert, C., van Langeveld, M.C. and Donoso, L.A. (2014) Innovations in 3D Printing: A 3D Overview from Optics to Organs. Br J Ophthalmol., 98, 159-161. http://dx.doi.org/10.1136/bjophthalmol-2013-304446

[5] Tokuuye, K., Akine, Y., Sumi, M., Kagami, Y., Ikeda, H. and Kaneko, A. (1997) Fractionated Stereotactic Radiotherapy for Choroidal Melanomas. Radiother Oncol., 43, 87-91. http://dx.doi.org/10.1016/S0167-8140(97)01910-5

[6] Tse, D. (2016) 3D Printed Facial Prosthesis Offers New Hope for Eye Cancer Patients Following Surgery. American Academy of Ophthalmology. 2014; Dostupné na internete. http://www.3ders.org/articles/20141021-3d-printed-facial-prosthesis-offers-new-hope-for-e ye-cancer-patients-following-surgery.html

[7] Valverde, I., Gomez, G., Suarez-Mejias, C., Hosseinpour, A.R., Hazekamp, M., Roest, A., Vazquez-Jimenez, J.F., El-Rassi, I., Uribe, S. and Gomez-Cia, T. (2015) 3D Printed Cardiovascular Models for Surgical Planning in Complex Congenital Heart Diseases. Journal of Cardiovascular Magnetic Resonance, 17, 196. http://dx.doi.org/10.1186/1532-429X-17-S1-P196

[8] Ventola, C.L. (2014) Medical Applications for 3D Printing: Current and Projected Uses. $P$ T., 39, 704-711. 
Submit or recommend next manuscript to SCIRP and we will provide best service for you:

Accepting pre-submission inquiries through Email, Facebook, LinkedIn, Twitter, etc. A wide selection of journals (inclusive of 9 subjects, more than 200 journals)

Providing 24-hour high-quality service

User-friendly online submission system

Fair and swift peer-review system

Efficient typesetting and proofreading procedure

Display of the result of downloads and visits, as well as the number of cited articles

Maximum dissemination of your research work

Submit your manuscript at: http://papersubmission.scirp.org/

Or contact jbm@scirp.org 